\title{
Modelling exchange rate variations and global shocks in Brazil ${ }^{*}$
}

\author{
Harold Ngalawa ${ }^{1}$, Adebayo Augustine Kutu ${ }^{2}$
}

\begin{abstract}
The purpose of this paper is to model variations of Brazil's exchange rates and global shocks in order to establish if global oil prices and international interest rates (global shocks) have any impact on exchange rate variations in Brazil. After establishing the existence of ARCH effects and ensuring the stationarity of the data set, we estimate the symmetric GARCH $(1,1)$ model along with two asymmetric EGARCH $(1,1)$ and APARCH $(1,1)$ models using the theoretical model of Kamal et al. (2012). The results show that the GARCH $(1,1)$ model provides the best fit for Brazil's exchange rate variations while the model selection chooses the Student's $t$ distribution as the preferable model of good fit compared to the alternatives. The study results show that Brazil's exchange rates are significantly influenced by global shocks. Accordingly, we recommend that the Brazilian government should consider the impact of oil prices and global interest rates when formulating and implementing policies that impact on the exchange rate.
\end{abstract}

Key words: modelling exchange rate variations, GARCH, EGARCH and APARCH models

JEL classification: $E 1, E 3, F 1$

* Received: 10-11-2016; accepted: 09-12-2016

1 PhD, Senior Lecturer, School of Accounting, Economics \& Finance, University of KwaZuluNatal, Westville Campus, Private Bag X54001, Durban, Republic of South Africa. Scientific affiliation: macro and monetary economics. Phone: +27031260 7558. E-mail: ngalawa@ ukzn.ac.za.

2 PhD Candidate, School of Accounting, Economics \& Finance, University of KwaZulu-Natal, Westville Campus, Private Bag X54001, Durban, Republic of South Africa. Scientific affiliation: macro and monetary economics. Phone: +270 71238 7450.E-mail: ade_kutu@yahoo.com (corresponding author). 


\section{Introduction}

Exchange rate variations have been a subject of research for many years due to their implications on business and policy decisions. Its global shocks tend to have real economic costs on price stability, firm profitability and a country's financial stability (Benita and Lauterbach, 2007). In Brazil, exchange rate variations influence trade volume and have a deleterious effect on the country's exports (Aguirre et al., 2007). The state in which manufacturers in the industrial sector produce goods and services locally and transport them across international borders form the basis upon which Brazil carries out business transactions with the rest of the world. The fact that trade is important and because it is connected to exchange rate variations, informs our desire to model exchange rate variations in Brazil amidst global shocks.

In the $20^{\text {th }}$ century, most countries experimented with various systems to stabilize their currencies, often by imposing regulations and restrictions on the exchange rate market, through their Central Banks. However, the Central Bank policies have only been partially successful in preventing and controlling exchange rate variations. In view of this development, there has been extensive research on the appropriate exchange rate system, especially in developing countries. The main views that have emerged in choosing among the types of exchange rate systems are: fixed exchange rate system, floating exchange rate system and pegged/managed float exchange rate system (Edwards et al., 2003 and Sullivan, 2001). Brazil has adopted a free-floating exchange rate system, which has helped to produce a unique and realistic exchange rate for the nation's currency. This is in line with the first view, which believes that with an increase in globalization and an attempt to edge against imposition, domestic policies and regulations tend to collapse naturally, the need for floating exchange rate system.

The opposing views maintain that there are still other countries which have chosen another "turning resolution" and have "pegged" their currencies to the Dollar or Euro (see Benita and Lauterbach, 2007). India as a member of BRICS countries (to which Brazil belongs) operates a crawling-peg exchange rate system. Its argument has been that even in a free-floating exchange rate system, most Central Banks still intervene in the foreign exchange market (see Calvo and Reinhart, 2002). The Central Banks, for example, still intervene in the selling and purchasing of currencies. They keep a threshold or exchange rate band and through their monetary policy tools, the Central Banks use the interest rates to respond to deviation of exchange rates from their targeted levels (Monacelli, 2004) to prevent changes in exchange rates.

Theoretically, variations in exchange rates can have a negative or positive impact on output growth. They can generate expenditure-switching effects between foreign and domestic goods, thus affecting net exports. They may further affect firms' profit margins and with possible second-round effects on investment. Duasa 
(2009) demonstrates that exchange rate variations significantly affect fluctuations of import prices and consequently affect economic activities. Furthermore, Kandil and Mirzaie (2005) reveal that the impact of exchange rate variations and exchange rate shocks is likely to determine economic performance, as some countries are highly susceptible to external shocks such as the exchange rate. Depreciation may stimulate economic activities through an initial increase in the prices of foreign goods while an appreciation decreases net export through the initial decrease in prices of foreign goods. Following the foregoing introduction and the objectives of the study, this study tests the hypothesis that global oil prices and international interest rates (global shocks) have no impact on exchange rate variations in Brazil.

Following this introduction, the rest of this paper is structured in five sections. Section 2 is a brief review of the literature; Section 3 outlines the methodology employed; Section 4 presents empirical data and analysis; Section 5 explains the results and their economic significance; and Section 6 concludes the paper.

\section{Literature review}

Various studies have modelled variations of exchange rates using different approaches such as the Generalized Autoregressive Conditional Heteroscedastic (GARCH), Exponential Generalized Autoregressive Conditional Heteroscedastic (EGARCH), Glosten, Jagannathan and Runkle - Generalized Autoregressive Conditional Heteroscedastic (GJR-GARCH), Ding, Granger and Engle-Generalized Autoregressive Conditional Heteroscedastic (DGE - GARCH), Threshold Autoregressive Conditional Heteroscedastic (TARCH) and Asymmetric Power Autoregressive Conditional Heteroscedastic (APARCH) among others. These approaches have played a vital role in financial forecasting, risk management and in an attempt to make financial decisions and predict the stability of the exchange rate. This section reviews the literature on the connection between exchange rate variations/volatility and global shocks.

Abdalla (2012) used both symmetric and asymmetric models to model exchange rate volatility in the Arab countries using daily observations over the period January 1, 2000 to November 19, 2011. Based on the $\operatorname{GARCH}(1,1)$ model, the results show that for ten out of nineteen currencies, volatility is an explosive process. The asymmetrical EGARCH $(1,1)$ results provide evidence of leverage effect for a majority of currencies, indicating that negative shocks imply a higher next period volatility than positive shocks of the same magnitude. The study concludes that the exchange rate volatility can be adequately modelled by the class of GARCH models. Ogundipe et al. (2014) focused on the impact of oil prices and exchange rate volatility on the Nigerian economy. They observed that a proportionate change in oil price leads to a more than proportionate change in exchange rate volatility in 
Nigeria; which implies that the exchange rate is susceptible to changes in oil price as a global shock.

Olowe (2009) modelled the volatility of Naira/Dollar exchange rates in Nigeria using GARCH $(1,1)$, GJR-GARCH $(1,1)$, EGARCH $(1,1)$, APARCH $(1,1)$, IGARCH $(1,1)$ and TS-GARCH $(1,1)$ models with monthly data over the period January 1970 to December 2007. He observed that the TSGARCH and APARCH models are the best models. In addition, Ün (2013) modelled the Mexico, Indonesia, South Korea and Turkey (MIST) Countries exchange rate volatility with Asymetric GARCH models for in sample and out of sample forecasting. The study employed monthly exchange rates against the US dollar over the period 1993:01 and 2012:12. The in-sample forecasting is estimated over the period between 199301 and 2012-12 and the out of sample forecasting over the period between 2012:12 and 2013:03. The result reveals an asymmetric and leverage effects and the best forecasting model was choosing in the estimated models. This finding is similar to Riman et al. (2013) that also modelled the asymmetric effect of oil price shocks on exchange rate volatility in Nigeria. The study concludes that volatility in crude oil prices has a negative impact on domestic investment, exchange rates and industrial development in Nigeria.

Furthermore, Thorlie et al. (2014) modelled the Sierra Leones/US exchange rate and examined the accuracy and forecasting performance of volatility models for the dollar's exchange rate return, including the ARMA, GARCH, Asymmetric GARCH and GJR-GARCH models with normal and non-normal (student's $t$ and skewed Student $t$ ) distributions. The study found that the Asymmetric (GARCH) and GARCH models better fit under the non-normal distribution than the normal distribution and improve the overall estimation for measuring conditional variance while the GJR-GARCH model using the skewed Student t- distribution is most successful and better forecast the Sierra Leone exchange rate volatility. Kamal et al. (2012) on the other hand examined the performance of GARCH family models (including symmetric GARCH-M, asymmetric EGARCH and TARCH models) in forecasting the volatility behavior of Pakistani foreign exchange market. In the study's results, the first order autoregressive behavior of the foreign exchange rate was evidenced in GARCH-M and E-GARCH models while the GARCH-M model supports that previous day foreign exchange rate affected the current day exchange rate. The EGARCH-based evaluation of foreign exchange rates showed asymmetric behavior of volatility, where TARCH model showed insignificance but detailed exploratory analysis of the foreign exchange rate behavior requires prolonged study by applying advance models.

Finally, Ramzan et al. (2012) modelled exchange rate dynamics in Pakistan using the ARCH family of models. The data used in the study consists of monthly exchange rates of Pakistan for the period ranging from July 1981 to May 2010. The result of GARCH $(1,2)$ is found to be best as compared to the EGARCH $(1,2)$ model. 


\section{Methodology}

To model exchange rate variations in Brazil, this study employs the MarshallLearner Condition of exchange rate determination. The Marshall-Learner Condition (propounded by Alfred Marshall and Abba P. Lerner) is an extension of Marshall's theory of the price elasticity of demand for foreign trade that can be linked to Brazil's trading activities with the rest of the world. Oladipupo (2011) explains the MarshallLearner Condition as the sum of the absolute long-term price-elasticities for exports and imports which has to be greater than unity (one) for it to cause a balance of trade improvement. The Marshall-Learner Condition can be expressed as:

$$
\Delta \forall=A B X\left(a_{1 n}+a_{2 n-1}\right)
$$

where:

$\Delta \forall=$ total change in the balance of trade

$A=$ percentage of devaluation of a currency (and - in this case - the Brazilian Real)

$B X=$ the value of (Brazilian) exports expressed in terms of foreign currency (United States dollars)

$a_{1 n}=$ the first devaluing country's price elasticity of demand for imports

$a_{2 n}=$ the second country's price elasticity of demand for exports from the devaluing country.

Therefore, for the Marshall-Learner Condition to be fulfilled, $a_{1 n}+a_{2 n-1}>1$. This approach gives a condition on which changes in exchange rates will have some impact on balance of trade (balance of payments) and restore equilibrium. A further expression for the restoration of the balance of payments equilibrium can also be given as:

$$
B=P_{x}^{*} X(s)-P_{m}^{*} M(s) B=P_{x}^{*} X(s)-P_{m}^{*} M(s)
$$

where:

$B$ = the balance of payments

$P_{x}^{*}=$ the price of exported goods

$P_{m}{ }^{*}=$ is the price of imported goods

$s \quad=$ price elasticity of exports and imports goods.

With equation (2) above, if

$P_{x}^{*}=P_{m}^{*}=1$; we have $B=X(s)-M(s)$,

therefore: 


$$
\frac{d B}{d s}=\frac{d X}{d s}-X(s)-\frac{d M}{d s}-M(s)
$$

Equation (3) can be re-expressed in terms of the home country's import elasticity of demand $\left(s_{m}\right)$ and foreign demand elasticity for the home country's exports $\left(s_{x}\right)$ where:

$$
\begin{aligned}
& s_{m}=-\frac{d M}{d s} \frac{s}{M} \\
& s_{x}=-\frac{d X}{d s} \frac{s}{X}
\end{aligned}
$$

we get $\frac{d B}{d s}>0$ e.g. a devaluation improves the balance of payments as long as $\frac{X}{s M} s_{x}+s_{m}-1>0$. In addition, if trade is balanced, then $\left(\frac{X}{S M}=1\right)$. In addition, trade improves if the price elasticity is high enough, e.g., $s_{x}+s_{m}>1$. However, if the balance of payment is initially in deficit, then the sum of trade elasticity with $s$ must be higher than unity.

\subsection{Scope of the study and variables}

This study spans the period between 1994:01 and 2013:12. The period chosen is dictated by data availability. The findings of each method employed will help in identifying a model with a better fit for the Brazilian economy. We examine four variables in the attempt to model exchange rate behaviour in Brazil. These can be grouped into domestic and foreign variables. The domestic variables are exchange rate (EX) and the lagged of exchange rate (EX(-1)) while the foreign variables are the international interest rate (proxied by Federal Funds Rate-FFR) and global oil prices (OP). All variables are consistent with the existing literature for modelling exchange rates (see Ün, 2013; Abdalla, 2012 and Thorlie et al., 2014). To the best of the researchers' knowledge, there is no published study of this nature on the Brazil economy. The study, therefore, contributes to the literature of exchange rate behavior in Brazil by attempting to find a model that best fits exchange rate fluctuations (variations) in the country.

\subsection{Definition of variables, data and data sources}

The Exchange Rate (EX), expressed in terms of the local currency to the US dollar is employed in order to establish the best fit in the trade relationship between Brazil and rest of the world while the lagged exchange rate (EX (-1)) is included consistent with Khosa et al. (2015). The global Oil Price (OP) is the commodity global spot 
price for oil quoted by the Organization of the Petroleum Exporting Countries (OPEC) and the Federal Funds Rate (FFR) is the United States of America's short term interest rate at which depository institutions in the country borrow from and lend to each other their Central Bank's balances, usually overnight. The variable is included to proxy international interest rates. Both oil prices and the international interest rates are exogenous variables included to capture the impact of external shocks on exchange rates in Brazil. They are used to control for the position of the global economy against the understanding that global business cycles exert a significant effect on the performance of Brazil's economy. Several studies have followed this line of thought (see Liu et al., 2015; Benita and Lauterbach, 2007; Elboune, 2008; Afandi, 2005; Maturu, 2007). In line with Nortey et al. (2015), monthly time series data is employed covering a period of twenty years from 1994:1 to 2013:12. The data are obtained from Brazil's Central Bank's statistical bulletins and the Statistics Offices.

\subsection{Model specification}

Three alternative methods of analyses are used. This study employs the Generalized Autoregressive Conditional Heteroscedasticity (GARCH), Exponential Generalized Autoregressive Conditional Heteroscedasticity (EGARCH) and Asymmetric Power Autoregressive Conditional Heteroscedasticity (APARCH) models. The different approaches used in the analyses are to provide a comprehensive methodology through which exchange rates can be effectively modelled for Brazil's economy. It is to further help in determining the extent (if any) of differences in the estimations with different measures of the exchange rates in Brazil. The construction of our GARCH, EGARCH and APARCH models follow the conventional method of Ebaidalla (2013:7) and Abdalla (2012:220) where the variance evolves over time and distinguishes one model from the other. The model is presented as:

$$
E X_{t}=\alpha_{0}+\alpha_{1} E X_{t-1}+\alpha_{2} F F R_{t}+\alpha_{3} O P_{t}+\varepsilon
$$

where $\varepsilon_{t} \sim N\left(O, h_{t}\right)$

$$
h_{t}=C_{0}+\beta_{1} h_{t-1}+\beta_{2} e_{t-1}^{2}+\beta_{3} F F R_{t}+\beta_{4} O P_{t}+\mu_{t}
$$

Equation 7 above is a dynamic model. It means that the conditional variance is a function of four terms: $C_{0}$ which is the constant term, $e_{t-1}^{2}$ (the ARCH term) is the previous period's squared residual from the mean equation, $h_{t}$ (the GARCH term) is the variance of the previous period's residual or exchange rate variations of the Brazilian economy and the two exogenous variables (FFR and $O P$ ). $\beta_{1}-\beta_{4}$ are coefficients of the dependent variables. 


\subsubsection{Model specification for GARCH $(1,1)$}

The GARCH process for modelling exchange rates can be given as:

$$
\begin{aligned}
& \sigma_{t}^{2}=\forall+\sum_{j=1}^{p} \alpha_{j} \sigma_{t-j}^{2}+\sum_{i=1}^{q} \beta_{i} \varepsilon_{t-i}^{2} \\
& \forall>0, \beta_{i} \geq 0, \alpha_{j} \geq 0, \quad i=1 \ldots \ldots q, j=1 \ldots \ldots \ldots \\
& Y_{t}=\beta+\alpha X_{t}+\gamma h_{t}+\varepsilon_{t} \\
& \varepsilon_{t /} \pi_{t} \sim N\left(0, h_{t}\right) \\
& h_{t}=\varphi_{0}+\sum_{i=1}^{p} \delta_{i} h_{t-1}+\sum_{j=1}^{q} \tau_{j} \varepsilon_{t-j}^{2}
\end{aligned}
$$

From the above equation, "the conditional variance is a linear function of $q$ lags of the squares of the error terms $\left(\varepsilon_{t}^{2}\right)$ or the ARCH terms and $p$ lags of the past values of the conditional variances $\left(\sigma_{t}^{2}\right)$ or the GARCH terms, and a constant $\forall$ (see Bollerslev, 1986 and Kamal et al., 2012)". The inequality restrictions were imposed to guarantee a positive conditional variance in the equation. Hansen and Lunde (2001) proved that the GARCH $(1,1)$ process is adequate enough to describe the features of the time series data and thereby allow the conditional mean to depend on its own conditional variance.

\subsubsection{Model specification for EGARCH $(1,1)$}

The commonly used EGARCH $(1,1)$ process for modelling exchange rates can be given as:

$$
\sigma_{t}^{2}=\alpha_{0}+\alpha_{1}\left[\frac{\mu_{t-1}}{\sigma_{t-1}}\right]+\beta_{1} \sigma_{t-1}^{2}+\gamma \frac{\mu_{t-1}}{\sigma_{t-1}}
$$

EGARCH was developed and presented by Nelson (1991) for an asymmetric response to exchange rate variations. The $\gamma$ term accounts for the presence of the leverage effects (large negative returns are more likely to forecast high variations than large positive returns) which makes the model asymmetric. When the asymmetric model for variations is applied, it allows the variation and shock to respond freely when the prices are falling due to the bad news than with corresponding increases due to the good news (Kamal et al., 2012). This means that the effect of good news, a positive lagged residual, may be different from the effects of a bad news, a negative legged residual. 


\subsubsection{Model specification for APARCH (1,1)}

Ding et al. (2001) introduced the Asymmetric Power Autoregressive Conditional Heteroscedasticity (APARCH) model. The model takes the asymmetric coefficient and the leverage effect into account by changing the second order of the error term into a more flexible varying exponent. It further represents a general class of models that include both ARCH and GARCH models. Therefore, the APARCH process for modelling exchange rates can be given as:

$$
\varepsilon_{t}=Z_{t} \sigma_{t} ; \sigma^{2} ; \sigma_{t}^{\delta}=w+\beta \sigma_{t-1}^{\delta}+\alpha\left[\left(\mu_{t-1}\right)-\gamma \mu_{t-1}\right]^{\delta}
$$

where $\gamma$ is the leverage parameter. In this model, $\mu_{t-1}>0$ stands for "good news" and $\mu_{t-1}<0$ stands for "bad news". Both have different effects on the conditional variance and it can be concluded that the news effect is asymmetric with the presence of leverage effects.

According to Ali (2013), some of the models that can be derived or estimated from this framework include:

- TS-GARCH when $\delta=1$ and $\gamma=0$

- GJR-GARCH when $\delta=2$

- T-ARCH of Zakoian when $\delta=1$

- Log ARCH when $\delta=0$

- N-ARCH of Higgins and Bera when $\delta=0$ and $\beta=0$

The difference between EGARCH and APARCH is that, EGARCH assumes the leverage effect is exponential while APARCH assumes the leverage effect as quadratic. The leverage effect is related to fluctuations (variations) observed in a financial and economic time series.

\subsection{Evaluation of models and model selection criteria}

Following Bala and Asemota (2013), the empirical analysis of this study employed three conditional distributions in order to properly evaluate the GARCH $(1,1)$, EGARCH $(1,1)$ and APARCH $(1,1)$ models to investigate exchange rate behavior in Brazil. These are:

- The Normal Gaussian distribution

- The Student's t distribution with fixed df

- The Generalized Error Distribution (GED) 


\subsubsection{The normal Gaussian distributions}

Under this distribution, the distributional assumptions to be tested are: (1) there is no serial correlation, (2) residuals are normally distributed and (3) there are no ARCH effects. The parameter $\theta=[\alpha, \beta, \gamma, \delta, \sigma, \pi, \tau$, and $\varphi]$ is derived from the maximization of the log likelihood function:

$$
\log L=\sum_{t=1}^{N} l_{t}=-\frac{N}{2} \log (2 \pi)-\frac{1}{2} \sum_{t=1}^{N} \log \sigma_{t}^{2}-\frac{1}{2} \sum_{t=1}^{N} \frac{\mu_{t}^{2}}{\sigma_{t}^{2}}
$$

where $N$ is the sample size, and

$$
l_{t}=-\frac{1}{2} \log (2 \pi)-\frac{1}{2} \log \left(\sigma_{t}^{2}\right)-\frac{1}{2}\left(y_{t}-x_{t-1}^{\prime} \gamma\right)^{2} / \sigma_{t}^{2}
$$

\subsubsection{The Student's $t$ with Fixed df}

For Student's $t$ with fixed degrees of freedom (df), the log likelihood distribution functions are assumed to be of the following form:

$$
l_{t}=-\frac{1}{2} \log \left[\frac{\pi\left[(v-2) \psi\left(\frac{\rho}{2}\right)\right]^{2}}{\psi[(\rho+1) / 2]^{2}}\right]-\frac{1}{2} \log \sigma_{t}^{2}-\frac{[v+1]}{2} \log \left[1+\frac{\left[\left(y_{t}-x_{t}^{\prime} \gamma\right]^{2}\right.}{\sigma_{t}^{2}[v-2]}\right]
$$

Where $\sigma_{t}^{2}$ represents the variance at time $t$, and the degree of freedom $(v>2)$ controls the detail behavior. The $t$-distribution method treats the normal as $v \rightarrow \infty$.

\subsubsection{The Generalized Error Distribution (GED)}

In addition, the Generalized Error Distribution (GED) log likelihood distribution functions are assumed to be presented in the following form:

$$
l_{t}=-\frac{1}{2} \log \left[\frac{\sigma[1 / r]^{3}}{\sigma[3 / r][r / 2]^{2}}\right]-\frac{1}{2} \log \sigma_{t}^{2}-\left[\frac{\sigma[3 / r]\left[y_{t}-x_{t}^{\prime} \gamma\right]^{2}}{\sigma_{t}^{2} \rho[1 / r]}\right]
$$

where the tail parameter $r>0$. The GED is normally distributed if $r=2$ and fattailed if $r<2$. Given, $y_{t}=x_{t}^{\prime} \gamma+\mu_{t}$, then $\mu_{t}=\left(y_{t}-x_{t}^{\prime} \gamma\right)$. Accordingly, all the necessary regularity conditions are assumed to be satisfied.

\subsection{Unit root tests}

Unit root tests are one of the pre-conditions for estimating a GARCH, EGARCH and APARCH models as all the variables must be stationary in order to prevent spurious results. The stationarity of the data is further necessary because a majority of economic data do exhibit a non-stationary trend which could lead to misleading 
results (see Heymans et al., 2014). This study employs the common tests of Dickey Fuller (DF), Augmented Dickey Fuller (ADF) and Phillips Perron as they are valid for large sample sizes (Ogundipe et al., 2014). These tests will be used to determine the order of integration of the variables employed. When a series is stationary in levels, it is said to be integrated to order zero $(\mathrm{I}(0))$. That is, there is no unit root. If a variable is differentiated once in order for it to be stationary, it is said to be integrated of order one. That is, I(1). The Dickey Fuller (DF), Augmented Dickey Fuller (ADF) and Phillips Perron unit root hypotheses to be tested are given by:

- H0: $\alpha=1$, the series is non-stationary

$-\mathrm{H} 1: \alpha<1$, the series is stationary

\subsection{Diagnostic tests and model selection criteria}

For the GARCH, EGARCH and APARCH to be properly evaluated and also determine the model selection criteria, this study employed the Akaike Information Criterion (AIC) and Schwarz Information Criterion (SIC) to model exchange rates in Brazil. The benchmark is such that the lower the value of AIC or SIC, the better the model (see Bala and Asemota, 2013). The Normal Gaussian distribution, the Student's t with fixed degrees of freedom and the Generalized Error Distribution (GED) models for the GARCH, EGARCH and APARCH will be tested for normality, serial correlation and autoregressive conditional heteroscedasticity (ARCH effect) in order to determine which model is of good fit. The correlogram square residual (Q-test) is employed to test for serial correlation while the JarqueBera statistics and ARCH tests are employed to test for normality of the residuals and conditional heteroscedasticity respectively. The hypotheses to be tested are:

(1) Serial correlation test

- H0: there is no serial correlation in the residuals

- H1: there is serial correlation in the residuals

(2) Normality test

- H0: residuals are normally distributed

- H1: residuals are not normally distributed

(3) Conditional Heteroscedasticity test

- H0: there is no heteroscedasticity (ARCH effect).

- H1: there is heteroscedasticity (ARCH effect). 


\section{Empirical data and analysis}

We begin by testing the hypotheses in the foregoing discussion. In addition, tests for ARCH effects and unit roots are done.

\subsection{Hypothesis testing}

The study finds sufficient evidence to reject the null hypothesis that global shocks have no impact on exchange rate variations in Brazil. Since the P-values are all significant at $5 \%$, the study fails to reject the alternative hypothesis that the global shocks impact exchange rate variations in Brazil.

\subsection{Test for the residuals/ARCH effects}

As earlier stated, the first pre-condition for carrying out GARCH, EGARCH and APARCH models is to examine the residuals of the series of exchange rates for evidence of heteroscedasticity and determine whether they exhibit ARCH effects. Using the LM-ARCH effect test as shown in figure 1, the residuals show a prolong period of low and high variations through which the exchange rate remains unstable.

Figure 1: Results of the residuals/ARCH effect test

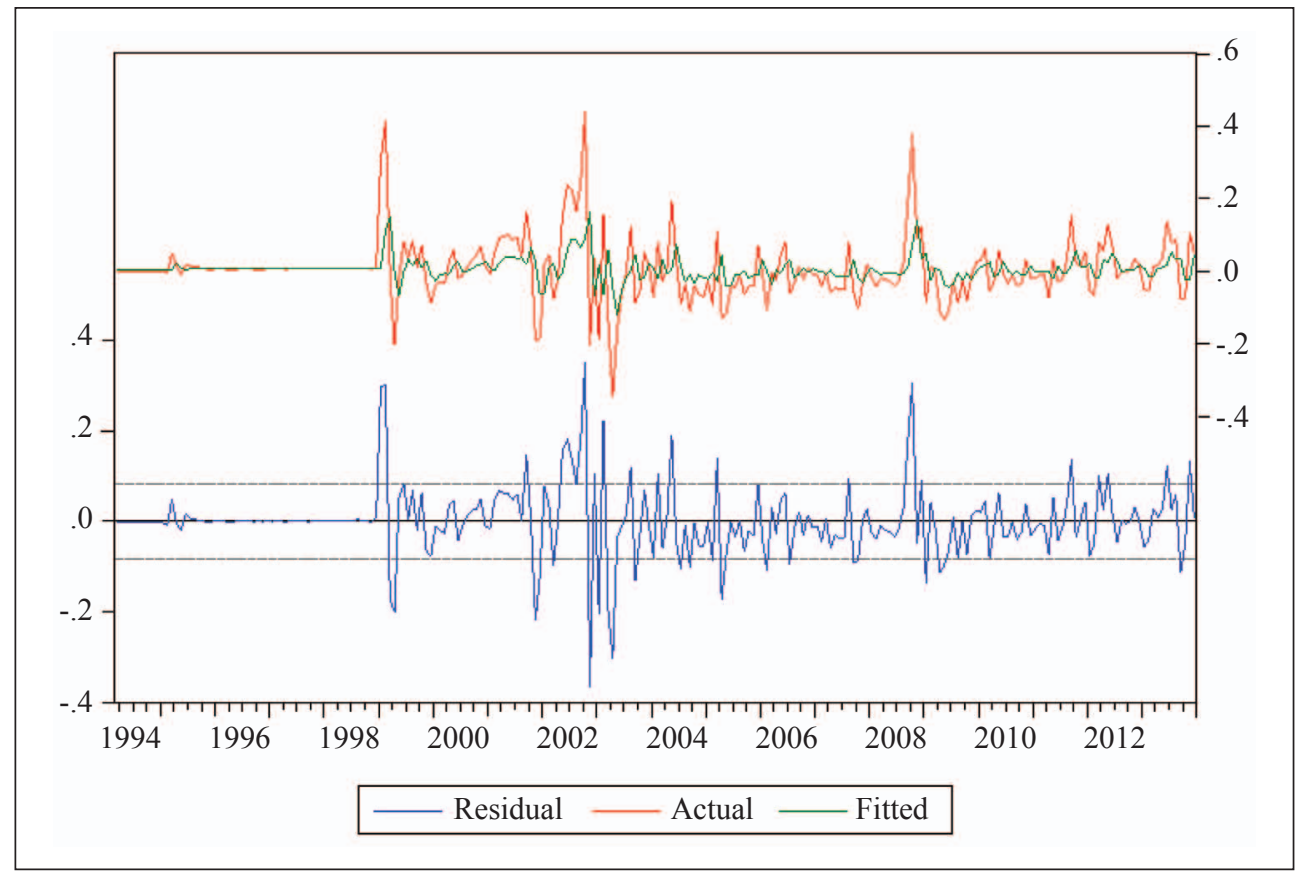

Source: Author's computation using data from Brazilian Central Bank statistical bulletins 
In Brazil, prolonged periods of low exchange rate variations are followed by prolonged periods of low exchange rate variations and prolonged periods of high exchange rate variations are followed by prolonged periods of high exchange rate variations. This suggests that the residual or error term exhibits clustering changes, revealing the presence of heteroscedasticity and $\mathrm{ARCH}$ effects. Hence, these can be presented by GARCH, EGARCH and APARCH models for analysis.

\subsection{Unit root tests}

Another pre-condition for carrying out GARCH, EGARCH and APARCH analyses is for the data to be stationary. Table 1 shows the results of the unit root tests for the Dickey Fuller (DF), Augmented Dickey Fuller (ADF) and Phillips Perron tests at individual intercept and trend. At 1\%,5\% and 10\% levels, we reject the hypothesis of unit roots in the data set and that all the series are stationary.

Table 1: The DF, ADF and P-P unit root tests

\begin{tabular}{|l|c|c|c|c|c|c|}
\hline \multirow{2}{*}{ Variable } & \multicolumn{2}{|c|}{$\begin{array}{c}\text { DF (individual intercept } \\
\text { and trend) }\end{array}$} & \multicolumn{2}{c|}{$\begin{array}{c}\text { ADF (individual } \\
\text { intercept and trend) }\end{array}$} & \multicolumn{2}{c|}{$\begin{array}{c}\text { P-P (individual } \\
\text { intercept and trend) }\end{array}$} \\
\cline { 2 - 7 } & $\begin{array}{c}\text { Order of } \\
\text { integration }\end{array}$ & P Value & $\begin{array}{c}\text { Order of } \\
\text { integration }\end{array}$ & P Value & $\begin{array}{c}\text { Order of } \\
\text { integration }\end{array}$ & P Value \\
\hline EX & $\mathrm{I}(1)$ & $0.0000^{* * *}$ & $\mathrm{I}(1)$ & $0.0000^{* * *}$ & $\mathrm{I}(1)$ & $0.0000^{* * *}$ \\
\hline EX(-1) & $\mathrm{I}(1)$ & $0.0000^{* * *}$ & $\mathrm{I}(1)$ & $0.0000^{* * *}$ & $\mathrm{I}(1)$ & $0.0000^{* * *}$ \\
\hline FFR & $\mathrm{I}(0)$ & $0.0000^{* * *}$ & $\mathrm{I}(1)$ & $0.0000^{* * *}$ & $\mathrm{I}(1)$ & $0.0000^{* * *}$ \\
\hline OP & $\mathrm{I}(1)$ & $0.0000^{* * *}$ & $\mathrm{I}(1)$ & $0.0108^{* *}$ & $\mathrm{I}(1)$ & $0.0484^{* *}$ \\
\hline
\end{tabular}

Note: $* * *, * *$ and $*$ represent statistical significance at $1 \%, 5 \%$, and $10 \%$ respectively.

Source: Author's computation using data from Brazil's Central Bank's statistical bulletins and the Statistics Offices

The results show that exchange rates, lagged exchange rates and global oil prices are not stationary in levels, but were integrated of order one, I(1) while international interest rates are either stationary in levels, $\mathrm{I}(0)$, or integrated of order one, $\mathrm{I}(1)$, as revealed by the different tests. These results are consistent with Khosa et al. (2015). Therefore, these results have satisfied the pre-condition for carrying out the GARCH, EGARCH and APARCH models.

\section{Results and discussion}

\subsection{Results of GARCH $(1,1)$ model for Brazil}

The GARCH parameters in Table 2 show the calculated values for the coefficients and P-values of the Normal Gaussian distribution, Student's $t$ distribution and 
the GED values for the monthly exchange rates in Brazil. The results show that the GARCH term, the ARCH term and the two exogenous shocks are important factors affecting exchange rates in Brazil. At $1 \%$, all the variables are statistically significant. The significant values of the GARCH (1) and the ARCH (1) terms imply that exchange rate variations are being affected by their GARCH and ARCH terms. In addition, the exchange rate at $t-1$ also significantly affects exchange rate variations in Brazil. This indicates that the past period of exchange rates variations is also significantly affecting the current exchange rates. This finding is consistent with Bala and Asemota (2013).

In addition, the two exogenous variables used to capture the impact of global shocks also contribute to the volatility of exchange rates in Brazil. This is consistent with Kin and Courage (2014) that global oil prices impact exchange rates. The negative coefficients of the international interest rates and global oil prices for all the models show that an increase in the global interest rate and oil price will lead to a depreciation of the currency. Alternatively, the negative sign shows that an increase in oil prices and global interest rates will affect exchange rates which in turn will cause a decrease in the Gross Domestic Product (GDP) and verse versa (Liu et al., 2015). This is in agreement with Aguirre et al. (2007) that study the impact of exchange rate volatility on Brazilian manufactured exports and find that exchange rate volatility has a significantly negative effect on Brazilian manufactured exports.

Table 2: Results of GARCH $(1,1)$ Model

\begin{tabular}{|c|c|c|c|c|c|c|}
\hline \multirow[t]{2}{*}{ Variable } & \multicolumn{2}{|c|}{$\begin{array}{l}\text { Normal Gaussian } \\
\text { distribution }\end{array}$} & \multicolumn{2}{|c|}{$\begin{array}{l}\text { Student's t with Fixed } \\
\text { df distribution }\end{array}$} & \multicolumn{2}{|c|}{$\begin{array}{c}\text { GED with Fixed } \\
\text { parameter distribution }\end{array}$} \\
\hline & Coefficient & P Value & Coefficient & $\mathrm{P}$ Value & Coefficient & P Value \\
\hline \multicolumn{7}{|c|}{ Mean Equation } \\
\hline $\mathrm{C}$ & $-6.21 E-05$ & 0.9887 & -0.001026 & 0.7826 & $-2.28 \mathrm{E}-05$ & 0.9955 \\
\hline $\operatorname{DEX}(-1)$ & 0.359774 & 0.0000 & 0.359476 & 0.0000 & 0.372295 & 0.0000 \\
\hline \multicolumn{7}{|c|}{ Variance Equation } \\
\hline$\gamma$ & 0.002779 & 0.0001 & 0.002514 & 0.0000 & 0.002467 & 0.0001 \\
\hline $\operatorname{ARCH}(-1)$ & 0.233330 & 0.0000 & 0.312995 & 0.0005 & 0.242132 & 0.0006 \\
\hline GARCH(-1) & 0.347540 & 0.0022 & 0.292613 & 0.0015 & 0.334083 & 0.0030 \\
\hline DFFR & -0.006674 & 0.0000 & -0.005817 & 0.0000 & -0.005875 & 0.0000 \\
\hline DOP & -0.000148 & 0.0006 & -0.000134 & 0.0008 & -0.000131 & 0.0021 \\
\hline \multicolumn{7}{|c|}{ Model Selection } \\
\hline AIC & & -2.580050 & & -2.876796 & & -2.710025 \\
\hline SIC & & -2.477924 & & -2.774670 & & -2.607899 \\
\hline
\end{tabular}

Source: Author's computation using data from Brazil's Central Bank's statistical bulletins and the Statistics Offices 
Considering the model selection criteria among the Normal Gaussian distribution, Student's $t$ distribution and the GED values, the Student's $t$ distribution is found to perform better than the Normal Gaussian distribution and the GED values as revealed by the values of the AIC and SIC. The lower the value of AIC and SIC, the better the fitness of the model. This is further confirmed in Table 3 where diagnostic tests are conducted on all the models. Under the Normal Gaussian distribution and the GED values, the models are serially corrected, the residuals are not normal and there is evidence of heteroscedasticity in the models. Hence, they cannot be used for policy formulation and forecasting of exchange rates in Brazil.

Table 3: Result of model selection for the GARCH $(1,1)$

\begin{tabular}{|l|c|c|c|}
\hline \multicolumn{1}{|c|}{ Model Type } & $\begin{array}{c}\text { Normal Gaussian } \\
\text { distribution }\end{array}$ & $\begin{array}{c}\text { Student's t } \\
\text { with Fixed df } \\
\text { distribution }\end{array}$ & $\begin{array}{c}\text { GED with } \\
\text { Fixed parameter } \\
\text { distribution }\end{array}$ \\
\hline Test & P Value & P Value & P Value \\
\hline No Serial Correlation & 0.0003 & 0.1032 & 0.0131 \\
\hline No ARCH Effect & 0.0033 & 0.1066 & 0.0140 \\
\hline Residuals are Normal & 0.0000 & 0.0000 & 0.0000 \\
\hline
\end{tabular}

Source: Author's computation using data from Brazilian Central Bank statistical bulletins and the Statistics Offices

Conversely, the Student's t distribution shows no evidence of serial correlation and no ARCH effect in the residuals. Hence, it is good for forecasting and policy formulation. This is a good sign for the model. However, the extreme large JarqueBera (JB) statistics for the model indicates non-normality of most of the series. This is a bad sign for the model, but researchers consider it as a "weaker sign" as it does not constitute a threat to the model and does not affect forecasting accuracy (see Bala and Asemota, 2013; Goyal and Arora, 2010).

\subsection{Results of EGARCH model for Brazil}

Table 4 presents results for the EGARCH $(1,1)$ model for Brazil. The EGARCH is an extension of the ARCH model to capture the asymmetric and leverage effects in the model as introduced by Nelson (1991). The capturing of asymmetric and leverage behaviour of Brazil's exchange rate is important for policymakers, individuals as well as investors in order to make them respond readily to exchange rate variations.

As revealed by the Normal Gaussian distribution, Student's t distributions and the GED values in Table 4, the results show that there is autoregressive behaviour in 
the exchange rates, as indicated by the significance (at $1 \%$ for all the models) of the term exchange rates at $t-1$ in the mean equation. This states that exchange rates variations in the past period are significantly affecting the current exchange rates. The constant term is also significant for the models. Under the variance equation, the asymmetric coefficients of the EGARCH (1) are significant at $1 \%$ indicating that the exchange rate in Brazil is also influenced by the EGARCH factor.

Table 4: Results of EGARCH $(1,1)$ Model

\begin{tabular}{|c|c|c|c|c|c|c|}
\hline \multirow[t]{2}{*}{ Variable } & \multicolumn{2}{|c|}{$\begin{array}{l}\text { Normal Gaussian } \\
\text { distribution }\end{array}$} & \multicolumn{2}{|c|}{$\begin{array}{c}\text { Student's } t \text { with Fixed } \\
\text { df distribution }\end{array}$} & \multicolumn{2}{|c|}{$\begin{array}{c}\text { GED with Fixed } \\
\text { parameter distribution }\end{array}$} \\
\hline & Coefficient & P Value & Coefficient & P Value & Coefficient & P Value \\
\hline \multicolumn{7}{|c|}{ Mean Equation } \\
\hline $\mathrm{C}$ & 0.001076 & 0.5757 & 0.003256 & 0.0000 & 0.001913 & 0.1071 \\
\hline $\operatorname{DEX}(-1)$ & 0.317411 & 0.0000 & 0.299209 & 0.0000 & 0.356979 & 0.000 \\
\hline \multicolumn{7}{|c|}{ Variance Equation } \\
\hline$\gamma$ & -0.993963 & 0.0000 & -0.374372 & 0.0000 & -1.223841 & 0.000 \\
\hline $\begin{array}{l}|\mathrm{RES}| / \mathrm{SQR} \\
{[\mathrm{GARCH}](1)}\end{array}$ & 0.326780 & 0.0002 & 0.276249 & 0.0000 & 0.520051 & 0.000 \\
\hline $\begin{array}{l}\text { RES/SQR } \\
{[\mathrm{GARCH}](1)}\end{array}$ & 9804 & 0.1175 & -0.130861 & 0.0052 & 0.014538 & 0.876 \\
\hline EGARCH(1) & 0.859773 & 0.0000 & 0.974465 & 0.0000 & 0.849921 & 0.0000 \\
\hline DFFR & -0.760530 & 0.0043 & -0.636966 & 0.0000 & -1.073266 & 0.0013 \\
\hline DOP & -0.012186 & 0.0806 & -0.010168 & 0.0929 & -0.010545 & 0.1859 \\
\hline \multicolumn{7}{|c|}{ Model Selection } \\
\hline AIC & & -2.797181 & & -3.234927 & & -2.996044 \\
\hline SIC & & -2.680466 & & -3.118212 & & -2.879329 \\
\hline
\end{tabular}

Source: Author's computation using data from Brazil's Central Bank's statistical bulletins and the Statistics Offices

The international interest rate also contributes to the exchange rate variations in Brazil as revealed by the models. In addition, the global oil prices are also significant at $10 \%$ for the Normal Gaussian distribution and Student's $\mathrm{T}$ distributions respectively. The implications of these results are that, global shocks are important determinants of exchange rate behavior in Brazil, hence, they must be put into consideration when formulating exchange rate policies. 
Harold Ngalawa, Adebayo Augustine Kutu $\bullet$ Modelling exchange rate variations...

Table 5: Result of model selection for the EGARCH $(1,1)$

\begin{tabular}{|l|c|c|c|}
\hline \multicolumn{1}{|c|}{ Model Type } & $\begin{array}{c}\text { Normal Gaussian } \\
\text { distribution }\end{array}$ & $\begin{array}{c}\text { Student's t } \\
\text { with Fixed df } \\
\text { distribution }\end{array}$ & $\begin{array}{c}\text { GED with } \\
\text { Fixed parameter } \\
\text { distribution }\end{array}$ \\
\hline Test & P Value & P Value & P Value \\
\hline No Serial Correlation & 0.3051 & 0.9540 & 0.9110 \\
\hline No ARCH Effect & 0.3114 & 0.9549 & 0.9125 \\
\hline Residuals are Normal & 0.0000 & 0.0000 & 0.0000 \\
\hline
\end{tabular}

Source: Author's computation using data from Brazilian Central Bank statistical bulletins and the Statistics Offices

The values of AIC and SIC support the Student's t distribution as the best fit. Nevertheless, the other two models (Normal Gaussian distribution and the GED values) display good performance in explaining the behaviour of exchange rates; and most of the coefficients of the mean and variance equations are significant. The p-values show no serial correlation and heteroscedasticity, hence, can still be recommended for policy formulation on exchange rate stability in Brazil.

\subsection{Results of APARCH model for Brazil}

APARCH parameters on monthly exchange rates are displayed in Table 6 where the output shows calculated coefficients and P-values of the Normal Gaussian distribution, Student's t distributions and the GED values. These results show autoregressive behaviour. In the mean equation, the exchange rate at $t-1$ is found to be significant at $1 \%$ for the three models. This implies that the one period lag of exchange rates in Brazil contribute to the present period's exchange rate variations and serve as an important factor in determining exchange rate variations. In the variance equation, the GARCH (1) term is found to be significant at $1 \%$ in all the models while the ARCH (1) terms are insignificant, indicating that the APARCH $(1,1)$ model is influenced by its $\mathrm{GARCH}$ term in determining exchange rate variations in Brazil.

In other word, the GARCH term serves as an important factor militating against exchange rates in Brazil while the ARCH does not. The two exogenous variables that capture external shocks are found to be significant at $1 \%$ and $10 \%$ respectively in all the models. 
Table 6: Results of APARCH $(1,1)$ Model

\begin{tabular}{|c|c|c|c|c|c|c|}
\hline \multirow[t]{2}{*}{ Variable } & \multicolumn{2}{|c|}{$\begin{array}{c}\text { Normal Gaussian } \\
\text { distribution }\end{array}$} & \multicolumn{2}{|c|}{$\begin{array}{c}\text { Student's t with Fixed } \\
\text { df distribution }\end{array}$} & \multicolumn{2}{|c|}{$\begin{array}{c}\text { GED with Fixed } \\
\text { parameter distribution }\end{array}$} \\
\hline & Coefficient & P Value & Coefficient & P Value & Coefficient & P Value \\
\hline \multicolumn{7}{|l|}{ Mean Equation } \\
\hline $\mathrm{C}$ & $-5.08 \mathrm{E}-05$ & 0.4722 & 0.004371 & 0.0000 & $-1.17 \mathrm{E}-05$ & 0.8386 \\
\hline $\operatorname{DEX}(-1)$ & 0.317416 & 0.0000 & 0.308527 & 0.0000 & 0.420249 & 0.0000 \\
\hline \multicolumn{7}{|l|}{ Variance Equation } \\
\hline$\gamma$ & -0.011359 & 0.0000 & $-8.05 E-05$ & 0.4072 & -0.006987 & 0.0000 \\
\hline ABS(RESID(-1) & 0.288451 & 0.0000 & 0.555477 & 0.0000 & 0.406466 & 0.0000 \\
\hline $\begin{array}{l}\operatorname{RESID}(-1)^{*} \\
\mathrm{ARCH}(1)\end{array}$ & -0.088600 & 0.5527 & -0.139448 & 0.1512 & -0.079030 & 0.5481 \\
\hline $\begin{array}{l}\text { SQRT } \\
(\text { GARCH(-1)) }\end{array}$ & 0.642420 & 0.0000 & 0.631602 & 0.0000 & 0.612515 & 0.0000 \\
\hline DFFR & -0.037226 & 0.0000 & -0.000535 & 0.0128 & -0.023006 & 0.0000 \\
\hline DOP & -0.000312 & 0.0963 & $-4.98 \mathrm{E}-05$ & 0.0975 & -0.000219 & 0.0655 \\
\hline \multicolumn{7}{|l|}{ Model Selection } \\
\hline AIC & & -2.836057 & & -3.480558 & & -3.054291 \\
\hline SIC & & -2.719342 & & -3.363843 & & -2.937576 \\
\hline
\end{tabular}

Source: Author's computation using data from Brazilian Central Bank statistical bulletins and the Statistics Offices

Accordingly, they also contribute to exchange rate variations in Brazil. Furthermore, the leverage effect term as represented by $y$ is significant for all the models, indicating that there is asymmetric behaviour and a presence of leverage effect. That is, the effects of good news and bad news on exchange rate variations in Brazil are asymmetric.

Table 7: Results of the selection for the APARCH $(1,1)$ Model

\begin{tabular}{|l|c|c|c|}
\hline \multicolumn{1}{|c|}{ Model Type } & $\begin{array}{c}\text { Normal Gaussian } \\
\text { distribution }\end{array}$ & $\begin{array}{c}\text { Student's t } \\
\text { with Fixed df } \\
\text { distribution }\end{array}$ & $\begin{array}{c}\text { GED with } \\
\text { Fixed parameter } \\
\text { distribution }\end{array}$ \\
\hline Test & P Value & P Value & P Value \\
\hline No Serial Correlation & 0.0730 & 0.9670 & 0.6530 \\
\hline No ARCH Effect & 0.0755 & 0.9676 & 0.6573 \\
\hline Residuals are Normal & 0.0000 & 0.0000 & 0.0000 \\
\hline
\end{tabular}

Source: Author's computation using data from Brazilian Central Bank statistical bulletins and the Statistics Offices 
Finally, while the value of AIC and SIC shows the Student's t distributions as the best fitted model, Table7 shows that both the Student's t distributions and the GED distributions perform better. They are found to outperform the Normal Gaussian distribution and can therefore be employed to forecast exchange rates and policy formulation in Brazil as no evidence of serial correlation and heteroscedasticity is found in the model.

\section{Conclusion}

The results obtained from various analyses in this study refute the hypothesis that global shocks do not have an impact on exchange rate variations in Brazil. The study finds strong evidence to support the hypothesis that global interest rates and global oil prices have a significant impact on exchange rate variations in Brazil. Results of the GARCH (1.1) model show that the previous period's exchange rates affect the current period's exchange rates in Brazil. In addition, variables that capture global shocks are observed to have the same effect. The EGARCH results from the Normal Gaussian distribution, Student's t distribution and the GED models have shown first order autoregressive behaviour in the exchange rates as revealed by the mean equations. The variance equations show asymmetric behaviour and evidence of leverage effects in which positive (good) and negative (bad) news have different impacts on exchange rates in Brazil. In addition, the results of the APARCH model also show and support asymmetric behaviour and evidence of leverage effects that negative shocks imply a higher next period conditional variance than positive shocks of the same magnitude. In the three different estimation techniques, the results of the GARCH $(1,1)$ model prove that this is the best model for modelling exchange rates and global shocks in Brazil since all the coefficients of the mean and variance equation are found to be statistically significant and support the hypothesis that global shocks impact exchange rate variations in the Brazil. Although it has successfully achieved its objectives, this study has its limitations. One such limitation is its inability, due to unavailability of data, to capture all monetary policy variables. In addition, only two external variables were used to explain the Brazilian exchange rate. These identified limitations can be focus areas for future research. Nonetheless, the obtained results have shed light on the importance of global shocks on exchange rate behaviour in Brazil. It can safely be recommended from the results of the study that monetary authorities should consider the impact of global shocks (especially oil prices and global interest rate) when formulating and implementing economic policies, especially as they relate to exchange rate. 


\section{References}

Abdalla, S. Z. S. (2012) "Modelling exchange rate volatility using GARCH models: Empirical evidence from Arab countries", International Journal of Economics and Finance, Vol. 4, No. 3, pp. 216-229, doi: 10.5539/ijef.v4n3p216.

Afandi, A. (2005) "Monetary policy transmission mechanism and structural breaks in Indonesia", $P h D$ thesis collection, University of Wollongong.

Aguirre, A., Ferreira, A. and Notini, H. (2007) "The impact of exchange rate volatility on Brazilian manufactured exports", Económica, p. 53.

Ali, G. (2013) "EGARCH, GJR-GARCH, TGARCH, AVGARCH, NGARCH, IGARCH and APARCH models for pathogens at marine recreational sites", Journal of Statistical and Econometric Methods, Vol. 2, No. 3, pp. 57-73.

Bala, D. A., Asemota, J. O. (2013) "Exchange-Rates Volatility in Nigeria: Application of GARCH Models with Exogenous Break", CBN Journal of Applied Statistics, Vol. 4, No. 1, pp. 89-116.

Benedictow, A., Boug, P. (2010) "Trade liberalisation and import price behaviour: the case of textiles and wearing apparels", doi: http://hdl.handle. net/11250/179983.

Benita, G., Lauterbach, B. (2007) "Policy factors and exchange rate volatility", International research journal of finance and economics, Vol. 7, No. 8, https:// faculty.biu.ac.i1/ lauteb/wp/4.pdf.

Bollerslev, T. (1986) "Generalized autoregressive conditional heteroscedasticity", Journal of econometrics, Vol. 31, No. 3, pp. 307-327, doi: 10.1016/03044076(86)90063-1.

Calvo, G., Reinhart, C. (2002) "Fear of floating", Quarterly Journal of Economics, Vol. 117, No. 2, pp. 379-408, http://www.tau.ac.il/ yashiv/fear_floating.pdf.

Chun, K. H. (2016) "The BRICs superpower challenge: foreign and security policy analysis", Routledge.

Chun, Z. (2013) "A promising partnership between BRICS and Africa: A Chinese perspective", THE CHINA MONITOR, p. 30.

Ding, Z., Granger, C.W., Engle, R. F. (2001) "January. A long memory property of stock market returns and a new model". In Essays in econometrics, pp. 349372, Harvard University Press, http://dl.acm.org/citation.cfm?id=781860.

Duasa, J. (2009) "Exchange rate shock on Malaysian prices of imports and exports: an empirical analysis", Journal of Economic cooperation and Development, Vol. 30, No. 3, pp. 99-114.

Ebaidalla, E.M. (2013) "Impact of exchange rate volatility on macroeconomic performance in Sudan", http://khartoumspace.uofk.edu/handle/123456789/18823.

Edwards, S. et al. (2003) "Exchange rate regimes". In Economic and financial crises in emerging market economies pp. 31-92, University of Chicago Press, doi: http://www.nber.org/chapters/c9774.pdf. 
Elbourne, A. (2008) "The UK housing market and the monetary policy transmission mechanism: An SVAR approach", Journal of Housing Economics, Vol.17 No.1, pp. 65-87, doi: 10.1016/j.jhe.2007.09.002.

Frenkel, J. A., Johnson, H. G. (2013) "The Economics of Exchange Rates" (Collected Works of Harry Johnson): Selected Studies, Vol. 8, Routledge.

Goyal, A., Arora, S. (2010) "A GARCH analysis of exchange rate volatility and the effectiveness of central bank actions", Indira Gandhi Institute of Development Research, Mumbay, pp. 1-19.

Hansen, P. R., Lunde, A. (2001) "A comparison of volatility models: Does anything beat a GARCH $(1,1)$ ", Centre for Analytical Finance, University of Aarhus, Working Paper Series, p. 84.

Heymans, A. et al. (2014) "Diligence in determining the appropriate form of stationarity" [Internet], http://dspace.nwu.ac.za/handle/10394/16664.

Kamal, Y., Ghani, U., Khan, M. M. (2012) "Modeling the exchange rate volatility, using generalized autoregressive conditionally heteroscedastic (GARCH) type models: Evidence from Pakistan", African Journal of Business Management, Vol. 6, No. 8, p. 2830, doi: 10.5897/ajbm10.1657.

Kandil, M., Mirzaie, I. (2005) "The effects of exchange rate fluctuations on output and prices: evidence from developing countries", The Journal of Developing Areas, pp.189-219.

Khosa, J., Botha, I., Pretorius, M. (2015) "The impact of exchange rate volatility on emerging market exports", Acta Commercii, Vol. 15, No. 1, pp. 1-11, doi: 10.4102/AC.v15i1.257.

Kin, S., Courage, M. (2014) "The Impact of Oil Prices on the Exchange Rate in South Africa", Journal of Economics, Vol. 5, No. 2, pp. 193-199.

Liu, H., Idrees, Z., Satti, J. A., Nazeer, A. (2015) "Exchange Rate Volatility and Oil Prices Shocks", International Journal of Academic Research in Business and Social Sciences, Vol. 5, No. 1, p. 249, doi: 10.6007/IJARBSS/v5-i1/1424.

Longmore, R., Robinson, W. (2004) "Modelling and forecasting exchange rate dynamics: an application of asymmetric volatility models", Bank of Jamaica, Working Paper WP2004/03.

Maturu, B. (2007) "Channels of monetary policy transmission in Kenya", Unpublished manuscript No. 1-25. A paper for presentation during the $12^{\text {th }}$ African Econometric Society Conference in Cape Town, South Africa, $4^{\text {th }}-6^{\text {th }}$, July 2007.

Miletić, S. (2015) "Modeling and forecasting exchange rate volatility: comparison between EEC and Developed countries", Industrija, Vol. 43, No. 1.

Monacelli, T. (2004) "Into the Mussa puzzle: monetary policy regimes and the real exchange rate in a small open economy", Journal of International Economics, Vol. 62, No. 1, pp. 191-217, doi: 10.1016/s0022-1996(03)00039-4. 
Nelson, D. B. (1991) "Conditional heteroskedasticity in asset returns: A new approach", Econometrica: Journal of the Econometric Society, Vol. 59, No. 2, pp. 347-370, doi: 10.2307/2938260.

Nortey, E. N., Ngoh, D. D., Doku-Amponsah, K., Ofori-Boateng, K. (2015) "Modeling inflation rates and exchange rates in Ghana: application of multivariate GARCH models", SpringerPlus, Vol. 4, No. 1, p. 1, doi: 10.1186/ s40064-015-0837-6.

Ogundipe, O. M., Ojeaga, P., Ogundipe, A. A. (2014) "Oil Price and Exchange Rate Volatility in Nigeria", Journal of Economics and Finance (IOSR), Vol. 5, No. 4, pp. 1-9.

Oladipupo, A.O. (2011) "Impact of exchange rate on balance of payment in Nigeria", African Research Review, Vol. 5, No. 4, doi: 10.4314/afrrev.v5i4.69260.

Olowe, R. A.(2009) "Modelling naira/dollar exchange rate volatility: application of GARCH and assymetric models", International Review of Business Research Papers, Vol. 5, No. 3, pp. 377-398.

Ramzan, S., Ramzan, S., Zahid, F. M. (2012) "Modeling and forecasting exchange rate dynamics in Pakistan using ARCH family of models", Electronic Journal of Applied Statistical Analysis, Vol. 5, No. 1, pp. 15-29, doi: 10.1285/ i20705948v5n1p15.

Riman, H. B., Akpan, E. S., Offiong, A. I. (2013) "Asymetric Effect of Oil Price Shocks on Exchange Rate Volatility and Domestic Investment in Nigeria", Vol. 4, No. 3, pp. 513-532, http://mpra.ub.uni-muenchen.de/53282/.

Schmitt-Grohé, S., Uribe, M. (2011) "Pegs and pain", National Bureau of Economic Research Working Paper No. w16847, doi: 10.3386/w16847.

Sullivan, E. J. (2001) "Exchange rate regimes: is the bipolar view correct?", Journal of economic perspectives, Vol. 15, No. 2, pp. 3-24, doi: 10.2469/dig.v31.n4.971.

Thorlie, M. A., Song, L., Wang, X., Amin, M. (2014) "Modelling Exchange Rate Volatility Using Asymmetric GARCH Models (Evidence from Sierra Leone)", International Journal of Science and Research (IJSR), Vol. 3, No. 11, pp. $1206-1214$.

Ün, A. T. (2013) "Modelling Exchange Rate Volatility in MIST Countries", International Journal of Business and Social Science, Vol. 4, No. 12. 


\title{
Modeliranje varijacija valutnih tečajeva i globalni šokovi u Brazilu
}

\author{
Harold Ngalawa', Adebayo Augustine Kutu ${ }^{2}$
}

\begin{abstract}
Sažetak
Svrha ovog rada je modeliranje varijacija brazilskih valutnih tečajeva i globalnih šokova kako bi se utvrdilo imaju li globalne cijene nafte i međunarodne kamatne stope (globalni šokovi) utjecaj na varijacije valutnog tečaja u Brazilu. Nakon utvrđivanja prisutnosti ARCH efekta i stacionarnosti zapisa podataka, procijenjeni su simetrični GARCH $(1,1)$ model zajedno s dva asimetrična modela EGARCH $(1,1)$ i APARCH $(1,1)$ koristeći teoretski model Kamala et al. (2012.). Rezultati pokazuju da GARCH $(1,1)$ model najbolje odgovara brazilskim varijacijama valutnog tečaja, dok se selektirani model Student t distribucija smatra poželjnim modelom koji se dobro uklapa u usporedbi s alternativama. Rezultati istraživanja pokazuju da globalni šokovi značajno utječu na brazilske valutne tečajeve. Stoga, preporuka je da brazilska vlada razmotri utjecaj cijena nafte i globalnih kamatnih stopa pri oblikovanju i provedbi politika koje utječu na valutni tečaj.
\end{abstract}

Ključne riječi: modeliranje varijacija valutnih tečajeva, GARCH, EGARCH $i$ APARCH modeli

JEL klasifikacija: E1, E3, F1

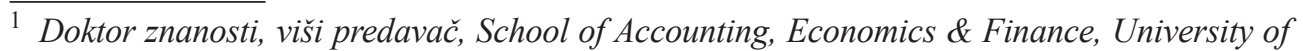
KwaZulu-Natal, Westville Campus, Private Bag X54001, Durban, Južnoafrička republika. Znanstveni interes: makroekonomija i monetarna ekonomija. Tel.: +27 0312607558. E-mail:ngalawa@ukzn.ac.za.

2 Doktorand, School of Accounting, Economics \& Finance, University of KwaZulu-Natal, Westville Campus, Private Bag X54001, Durban, Južnoafrička republika. Znanstveni interes: makroekonomija i monetarna ekonomija. Tel.: +27 071238 7450, E-mail: ade_kutu@yahoo.com (osobaza kontakt). 